VERTAISARVIOITU

KOLLEGIALT GRANSKAD

PEER-REVIEWED

www.tsv.fi/tunnus

\title{
SUOMALAISTEN NAISOPISKELIJOIDEN LUENNAN PERUSTAAJUUDEN MUUTOS 1990-LUVULTA 2010-LUVULLE
}

\author{
Anne-Maria Laukkanen, Puheen ja äänen tutkimuksen \\ laboratorio, Yhteiskuntatieteiden tiedekunta, \\ Tampereen yliopisto
}

\section{Teija Waaramaa, Puheen ja äänen tutkimuksen laboratorio, Yhteiskuntatieteiden tiedekunta, Tampereen yliopisto}

\begin{abstract}
Puhekorkeus on sekä yksilöllinen ja tilannekohtainen että myös sosiaalinen muuttuja. Eri maissa on viimeisen sadan vuoden aikana raportoitu naisten puhekorkeuden laskua. Puhekorkeuden muutoksen oletetaan heijastelevan yhteiskunnallisia muutoksia. Keskimääräistä puhekorkeutta mitataan usein perustaajuuden keskiarvolla ja mediaanilla. Tässä tutkimuksessa tarkastellaan suomalaisten yliopistossa opiskelevien naisten perustaajuuden (fo) keskiarvoa ja mediaania 160-sanaisessa, noin minuutin mittaisessa neutraalissa tekstiluennassa, joka on äänitetty 1990- ja 2010-luvuilla. Tutkimuksen aineisto on peräisin Tampereen yliopiston Puheen ja äänen tutkimuksen laboratorion äänitearkistosta. Tutkimukseen valittiin satunnaisesti 136 (N) 20-25-vuotiasta naista, joilla ei ollut tiedossa ääntöelimistön tai kuulon sairauksia, ja joiden ääni oli kuulonvaraisesti arvioituna normaali. Näytteet oli taltioitu vaimennetussa äänitysstudiossa digitaalisesti mittamikrofonia käyttäen, ja ne analysoitiin Praat-ohjelmalla. Perustaajuuden keskiarvo näyttää nousseen aiemmasta 195,7 Hz:stä 210,6 Hz:iin ja mediaani 190,9 Hz:stä 203,2 Hz:iin. Muutokset ovat tilastollisesti merkitseviä (Studentin t-testi, $p=<0,001$ molemmissa). Vieraiden kielten ja globaalin viihdekulttuurin vaikutus voinee osaltaan selittää muutosta.
\end{abstract}

Avainsanat: $f o$, kulttuurin vaikutus, puhekorkeus

\footnotetext{
Kirjoittajien yhteystiedot:

Anne-Maria Laukkanen

Teija Waaramaa

anne-maria.laukkanen@tuni.fi

teija.waaramaa@tuni.fi
} 


\section{JOHDANTO}

Totunnainen keskimääräinen puhekorkeus on sekä yksilöllinen ja tilannekohtainen että myös sosiaalinen muuttuja. Siihen vaikuttavat muun muassa puhujan sukupuoli, ikä, fyysinen koko, ääniluokka (esim. onko henkilö basso vai tenori, altto vai sopraano) sekä yksilölliset ja kulttuuriset ääni-ihanteet (Pegoraro-Krook, 1988; Scherer \& Giles, 1979; Vucovic, Feinberg, DeBruine, Smith, \& Jones, 2010). Luonnollisesti puhetilanne ja puhevoimakkuus (Harris \& Weiss, 1964; Zraick, Gentry, Smith-Olinde \& Gregg, 2006), tunnetila (Laukkanen, Vilkman, Alku \&Oksanen, 1997; Waaramaa-Mäki-Kulmala, 2009; Williams \& Stevens, 1972), terveydentila (Baken \& Orlikoff, 2000; Nilsonne, 1987) ja muut vastaavat tekijät tuottavat puhekorkeuteen lyhyen aikavälin muutoksia. Puhekorkeuteen on myös liitetty oletettuja tai todellisia persoonallisuuspiirteitä. Siinä, millaisia persoonallisuuspiirteitä erilaiseen puhekorkeuteen liitetään, on puolestaan todettu eroja kulttuurien välillä (Scherer, 1979). Puhekorkeus voi myös heijastella sosiaalisia suhteita ja niiden muutoksia (van Bezooijen, 1995).

Puhekorkeuden akustisena korrelaattina voidaan käyttää neutraalin puhe- tai luentanäytteen perustaajuuden $(f o)$ aritmeettista keskiarvoa, mediaania tai moodia (esim. Baken \& Orlikoff, 2000). Useimmissa tutkimuksissa on käytetty fo-keskiarvoa. Perustaajuus viittaa periodisen akustisen signaalin periodipituuteen. Fysiologisesti se vastaa äänihuulten värähtelytaajuutta. Perustaajuuden yksikkönä käytetään hertsiä $(1 \mathrm{~Hz}=1$ värähdys sekunnissa). Yleisesti ottaen miesten puheen keskimääräinen perustaajuus on 100 $\mathrm{Hz}$ ja naisten noin $200 \mathrm{~Hz}$ (Titze, 2000).

Pemberton, McCormack ja Russell (1998) ovat raportoineet naisten puheen keskimääräisen $f o$ :n laskusta viime vuosituhannen ai- kana. Pemberton ym. tutkivat tupakoimattomien, terveiden 18-25-vuotiaiden australialaisnaisten äänien akustisten ominaisuuksien eroja sukupolvien välillä. Osallistujien iän rajauksella pyrittiin poistamaan murrosiän, vaihdevuosien ja vanhuuden vaikutukset fo:an. Samoin kulttuurin, murteen, kielen ja koulutustaustan vaikutukset pyrittiin rajaamaan pois valitsemalla koehenkilöiksi vain australianenglantia äidinkielenään puhuvia koehenkilöitä, joilla oli kolmannen asteen koulutus. Tutkimuksessa käytettiin aineistona kahdelta eri henkilöryhmältä vuosina 1945 ( $\mathrm{n}=28)$ ja 1993 ( $\mathrm{n}=28)$ tallennettuja samoja luentanäytteitä (25 standardlilausetta). Tutkijat havaitsivat, että myöhemmin tallennetuissa näytteissä naisten $f o$ oli matalampi kuin aiemmin tallennetuissa näytteissä; $f o$ oli laskenut keskimäärin $23 \mathrm{~Hz}, 229 \mathrm{~Hz}$ :stä (keskihajonta 12,3 Hz) $206 \mathrm{~Hz}$ :in (keskihajonta 13,6 $\mathrm{Hz}$ ). Tulos oli tilastollisesti merkitsevä (OneWay Analysis of variance, FI,54 = 44,08, p = $.000)$. Samassa artikkelissa tutkijat listasivat myös vastaavanlaisia aiemmin eri maissa raportoituja tuloksia naisten keskimääräisestä fo:sta. Listauksen mukaan 70 vuoden aikavälillä, vuodesta 1924 vuoteen 1993 mennessä, naisten fo näyttäisi laskeneen $318 \mathrm{~Hz}$ :stä 206 Hz:in. Myöskin Suomessa tehdyssä tutkimuksessa Leino, Laukkanen, Kättö, Mäki \& Ilomäki (1998) löysivät pienen, mutta tilastollisesti merkitsevän laskun yliopistossa opiskelevien naisten luennan perustaajuudessa verrattaessa 1970-luvulla ja 1990-luvulla äänitettyjä näytteitä. Fo-keskiarvo oli laskenut 201,4 Hz:stä 196,7 Hz:iin jafo-moodi oli laskenut 194,5 Hz:stä 186,2 Hz:iin (Studentin t-testi, $\mathrm{p}=<0,05$ ja $\mathrm{p}=<0,001)$. Näytteenä oli käytetty samaa 160 sanan tekstikatkelmaa.

Varsinkin varhaisimpiin, viime vuosisadan alussa saatuihin puhekorkeustuloksiin tulee suhtautua varauksellisesti, koska niissä ei ole raportoitu, millaisesta näytteestä tulos on saatu ja koska myös tallennus- ja mittausteknii- 
kan erot saattavat vaikuttaa tuloksiin. Näistä varauksista huolimatta vastaavan suuntaisia tuloksia on kertynyt jo siinä määrin, että naisten $f o$ :n lasku näyttää selvältä ja laajalti esiintyvältä ilmiöltä.

Naisten puheen perustaajuuden laskua on selitetty sillä, että matalaan puheääneen on liitetty positiivinen arvovaraus. Kuuntelukokeissa on saatu tuloksia, että naisten korkea $f_{o}(\sim 280 \mathrm{~Hz})$ on koettu epämiellyttäväksi, ja tutkijat ovat tulkinneet liian korkean $f o$ :n ilmentävän lapsenomaisuutta ja seksuaalista kypsymättömyyttä (Borkowska \& Pawlowski, 2011). Matalaänisten naisten on puolestaan kuvattu antavan itsestään vakavasti otettavan ja kypsän vaikutelman, etenkin mediassa, ja mediassa esiintyvien naisten $f o$ :aa on pyritty myös tietoisesti madaltamaan (Pemberton ym., 1998). Niin ikään naisten $f_{0}$ :n laskun on oletettu myös heijastavan naisten aiempaa suurempaa ja tasa-arvoisempaa osallistumista yhteiskunnan eri osa-alueilla kodin ulkopuolella miesten rinnalla ja lisääntynyttä valtaa niin poliittisessa kuin taloudellisessakin päätöksenteossa. Fo:n laskua on selitetty naisten pyrkimyksellä adaptoitua miesvaltaiseen työympäristöön tai korkeaan valta-asemaan, jossa matala ääni ilmentää dominanssia (Borkowska \& Pawlowski, 2011; Lieberman, 1967; Ohala, 1983).

Tutkimustulosten valossa puheen keskimääräisen perustaajuuden muutokset näyttävät liittyvän sekä sosiaaliseen vuorovaikutukseen että sukupolvet ylittävään yhteiskunnalliseen muutokseen. Puheen perustaajuuden voidaan ajatella ilmentävän yhteiskunnan psykososiaalisia valtarakennelmia ja sosiaalisia rooleja, minkä vuoksi on kiinnostavaa tutkia, millaisia mahdollisia muutoksia naisten puheen perustaajuudessa on tapahtunut lähivuosikymmenten aikana ja noudattavatko muutokset aiemmin todettua laskusuuntaa. Viimeisimmät suurehkoon aineistoon (200 puhujaa) perustuvat tulokset suomalaisten naisten puhekorkeudesta koskevat yliopisto-opiskelijoita 1990-luvulla (Leino ym., 1998). Tämä tutkimus on jatkoa kyseiselle selvitykselle. Pyrimme vastaamaan kysymykseen, onko nuorten suomalaisten yliopistossa opiskelevien naisten luennan keskimääräinen perustaajuus ja sen vaihtelulaajuus muuttunut verrattaessa 1990-luvulla ja 2010-luvulla äänitettyä materiaalia. Kyseessä on retrospektiivinen tutkimus, jonka aineisto saatiin Tampereen yliopiston Puheen ja äänen tutkimuksen laboratorion äänitearkistosta.

\section{AINEISTO JA MENETELMÄT}

Tutkimusaineisto saatiin Tampereen yliopiston Puheen ja äänen tutkimuksen arkistosta. Valitsimme satunnaisesti 136 iältään 20-25-vuotiasta naista, joilla ei ollut tiedossa äänielimistön tai kuulon sairauksia, ja joiden ääni oli kuulonvaraisesti arvioituna normaali. Tutkimushenkilöistä 68 oli äänitetty vuosina 1991-1995 ja toiset 68 oli äänitetty vuosina 2015-2019. Kummankin aikakauden tutkimushenkilöiden oppiainekirjo oli varsin laaja. Tutkimushenkilöiden murretausta, mahdollinen kaksikielisyys yms. ei ole tiedossa, mutta kaikissa näytteissä luenta kuulosti varsin neutraalilta yleiskieleltä. Tutkimushenkilöt olivat lukeneet saman proosatekstikatkelman (Lauri Viidan kirjasta Moreeni; 160 sanaa, luentanäytteen kesto noin 1 minuutti) osana perusopintoihin kuuluvaa puhetekniikan ja äänenkäytön kurssia. Tekstikatkelma on sama, mitä Leino ym. käyttivät tukimuksessaan 1998. Optimaalinen kesto perustaajuusanalyysiä varten on minuutti (Zraick, Birdwell, \& Smith-Olinde, 2005). Kaikille tutkimushenkilöille oli annettu ohjeeksi lukea teksti omalla tavanomaisella puhetavallaan, keskustelupuhevoimakkuudella ilman erityistä taiteellista tai muuta tulkintaa. Näytteet oli äänitetty akustisesti vaimennetussa äänitysstudiossa digitaalisesti käyttäen $44.1 \mathrm{kHz}: \mathrm{n}$ 
näytteenottotaajuutta ja 16 bitin syvyyttä. Ä̈̈nitykset oli tehty 1990-luvulla Bruel \& Kjaer 4165-mittamikrofonilla ja 2010-luvulla Bruel Kjaer Mediator 2238 -mittamikrofonilla. Mikrofonietäisyys oli kummassakin aineistossa $40 \mathrm{~cm}$ puhujan huulista.

Perustaajuusanalyysi tehtiin Praat-ohjelmalla (versio 5.4.05; Boersma \& Weenink, 2010) autokorrelaatiomenetelmää käyttäen. Fo-analyysin raja-arvoina käytettiin 130-415 $\mathrm{Hz}$, jotta mahdolliset narinataajuudet jäisivät pois eivätkä vär̈ristäisi tulosta (ks. Ketolainen, Laakso \& Simberg, 2017). Analyysin aikaikkuna oli 0,01 sekuntia. Fo-analyysin raja-arvojen soveltuvuus tarkistettiin näytekohtaisesti ennen automaattista analyysiä tarkastelemalla signaalin aaltomuodosta ja FFT-spektristä saatavia $f o$-arvoja. Automaattinen perustaajuusanalyysi antoi kustakin näytteestä $f o$-keskiarvon, -mediaanin ja $f o$ :n vaihtelulaajuutta kuvaavan keskihajonnan. Perustaajuusanalyysin tulosta tarkasteltiin myös visuaalisesti fo-käyrän avulla. Automaattisen perustaajuusanalyysin selvät virheet (oktaavihypyt ja perustaajuuslukemat näytteen soinnittomissa kohdissa) poistettiin manuaalisesti. Fo:n keskihajonta ilmaistiin puolisävelaskelina, jotta eri korkeudelta puhuvien tutkimushenkilöiden näytteet olisivat keskenään vertailukelpoisia. Puolisävelasteikko (musiikkiasteikko) on logaritminen ja vastaa kuulohavaintoa. Yhtä suurelta kuulostava yhden puolisävelen ero sävelkorkeudessa vaikkapa välillä $\mathrm{f}$-fis on hertseissä ilmaistuna noin $10,4 \mathrm{~Hz}$, kun taas oktaavia korkeammalla vastaava yhden puolisävelaskelen ero välillä f1-fis1 on $20,76 \mathrm{~Hz}$.

Tuloksia tarkasteltiin tilastollisesti SPSSohjelmalla (versio 24). Kolmogorovin-Smirnovin-testillä todennettiin, noudattavatko parametrit normaalijakaumaa. Riippumattomien muuttujien jakaumia verrattiin keskenään Studentin t-testillä, mikäli parametrit noudattivat normaalijakaumaa. Muussa tapauksessa käytettiin ei-parametrista Mann-
Whitney U-testiä. Lisäksi korrelaatioanalyysillä tarkasteltiin perustaajuuden ja sen hajonnan mahdollisia yhteyksiä tutkimushenkilöiden ikään ja opiskelualaan. Normaalijakautuneille parametreille laskettiin Pearsonin korrelaatiokerroin, muita tarkasteltiin Spearmanin järjestyskorrelaatiokertoimen avulla. Varianssianalyysin avulla selvitettiin, eroavatko eri oppialojen edustajat toisistaan luennan perustaajuuden ja sen vaihtelulaajuuden suhteen.

\section{TULOKSET}

Ikä ei eronnut merkitsevästi kahden tutkimusryhmän välillä (Mann-Whitneyn Utesti, $\mathrm{p}=0,719$ ). Iän keskiarvo oli 1990-luvun ryhmässä 22,22 vuotta (SD 1,39 v) ja 2010-luvun ryhmässä 22,29 vuotta (SD 1,43 v). Kuvio 1 havainnollistaa oppialajakaumaa tarkastelluissa ryhmissä. Kummassakin ryhmässä yli 70\% osallistujista opiskeli kieli- tai yhteiskunnallisia aloja. Erona ryhmien välillä oli se, että 1990-luvulla kolmanneksi suurin oppialaedustus oli taideaineissa (20,6\%), kun taas 2010-luvulla toiseksi suurin edustus oli kasvatusaloilla (27,9\%)

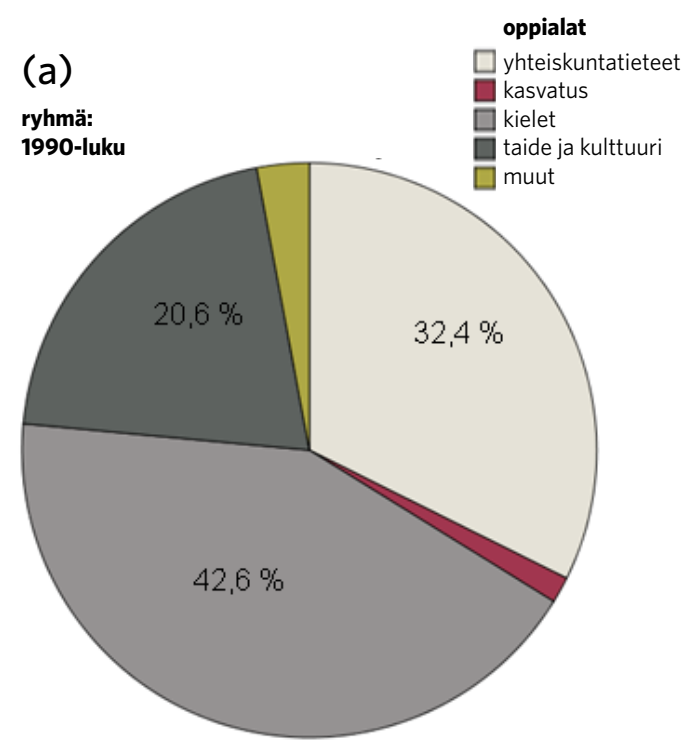


(b)

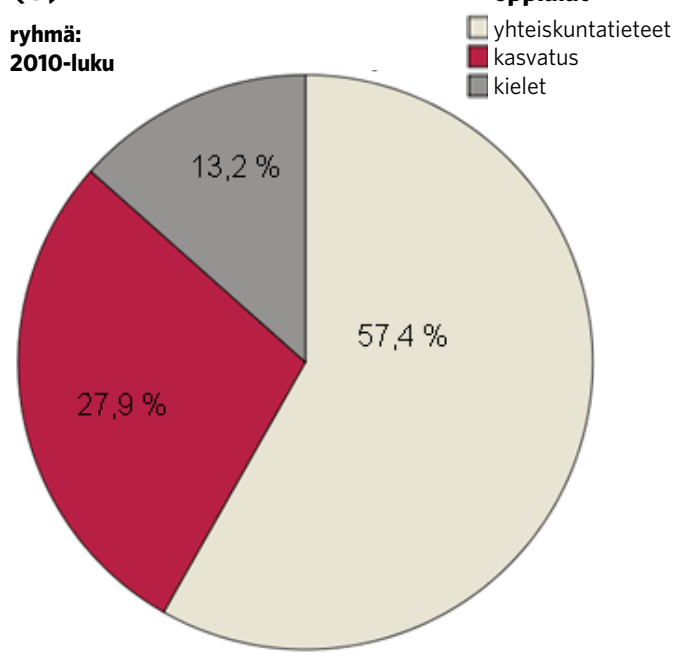

KUVIO 1. Tutkimusryhmien oppialajakaumat 1990-luvulla (a) ja 2010-luvulla (b).
Kuvio 2 havainnollistaa puhekorkeusanalyysitulosten jakautumista 1990- ja 2010-luvuilla. Taulukko 1 tiivistää perustaajuuden keskiarvotulokset. Niiden mukaan naisopiskelijoiden fo-keskiarvo tekstiluennassa näyttäisi nousseen noin $14,9 \mathrm{~Hz}$, mikä vastaa suunnilleen yhtä puolisävelaskelta. Vastaavasti $f o$-mediaani on noussut $12,3 \mathrm{~Hz}$. Erot ovat pieniä mutta tilastollisesti merkitseviä (ks. Taulukko 1). Fo:n vaihtelulaajuus (näytekohtainen $f o$ hajonta puolisävelaskelina ilmaistuna) näyttää pysyneen samana: keskiarvo 2,3 puolisävelaskelta ja keskihajonta 0,43 puolisävelaskelta kummassakin aineistossa (Mann-Whitneyn U-testi, $\mathrm{p}=0,518$.

TAULUKKO 1.

(a) Suomalaisten naisopiskelijoiden luennan perustaajuustulokset 1990-ja 2010-luvuilla.

\begin{tabular}{|c|c|c|c|c|c|}
\hline & ryhmä & N & KA & s & S \\
\hline fo $(K A)$ & 1990-luku & 68 & 195,74 & 16,75 & 2,03 \\
\hline & 2010-luku & 68 & 210,6 & 19,65 & 2,38 \\
\hline fo $(M d)$ & 1990-luku & 68 & 190,87 & 20,65 & 2,5 \\
\hline & 2010-luku & 68 & 203,25 & 19,74 & 2,39 \\
\hline
\end{tabular}

(b) Perustaajuustulosten vertailu riippumattomien muuttujien t-testillä.

\begin{tabular}{|c|c|c|c|c|c|c|c|c|c|}
\hline & \multicolumn{2}{|c|}{ Levene-testi } & \multicolumn{3}{|c|}{ t-testi } & & & LV (95\%) & \\
\hline & $\mathrm{F}$ & Sig. & $\mathrm{t}$ & $\mathrm{df}$ & $\mathrm{p}$ & $\begin{array}{c}\text { mean } \\
\text { diff. }\end{array}$ & $\begin{array}{c}\text { st. error } \\
\text { diff. }\end{array}$ & alaraja & yläraja \\
\hline & & & & & & & & & \\
\hline fo $(K A)$ & 1,63 & 0,20 & $-4,75$ & 134,00 & 0,00 & $-14,87$ & 3,13 & $-21,06$ & $.8,68$ \\
\hline fo $(M d)$ & 0,28 & 0,60 & $-3,57$ & 134,00 & 0,00 & $-12,38$ & 3,47 & $-19,24$ & $-5,53$ \\
\hline
\end{tabular}

Perusjoukkojen varianssit yhtä suuret. 


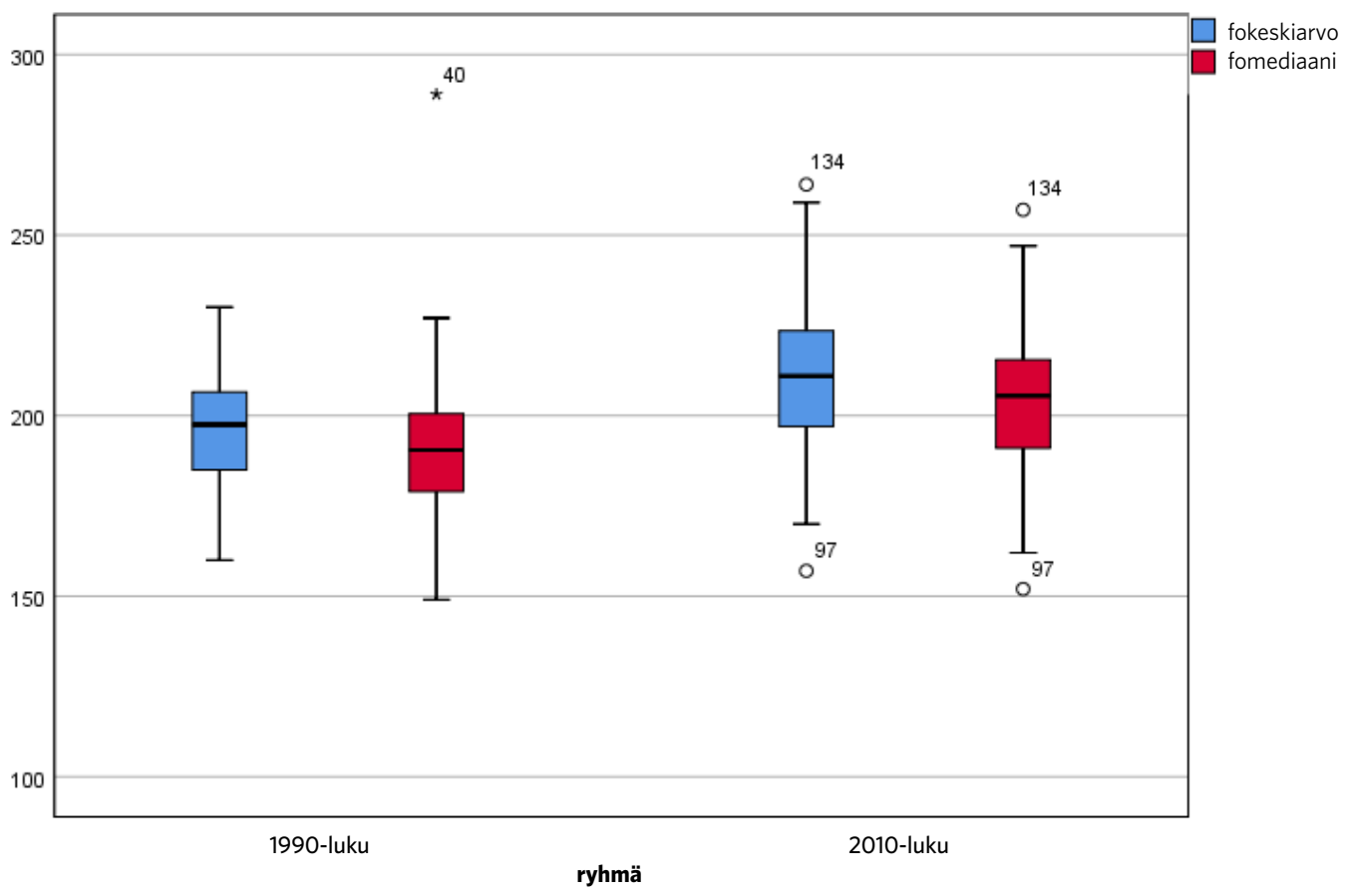

KUVIO 2. Luennan fo-analyysitulosten jakautuminen 1990-luvulla ja 2010-luvulla.

TAULUKKO 2.

Suomalaisten naisopiskelijoiden luennan perustaajuusanalyysitulosten suhde ikään ja oppialaan 1990-Iuvulla ja 2010-Iuvulla.

\begin{tabular}{|c|c|c|c|c|}
\hline 1990-luku & Korrelaatiot & fo keskiarvo & fo mediaani & fo keskihajonta \\
\hline ikä & rho & $-0,12$ & $-0,11$ & $-0,11$ \\
\hline & $p$ & 0,32 & 0,39 & 0,35 \\
\hline oppialat & rho & 0,03 & 68 & 68 \\
\hline & $p$ & 0,83 & 0,06 & $-0,18$ \\
\hline 2010-luku & Korrelaatiot & fo keskiarvo & fo mediaani & fo keskihajonta \\
\hline ikä & rho & $-0,03$ & $-0,02$ & 0,04 \\
\hline & $p$ & 0,82 & 0,87 & 0,72 \\
\hline & $N$ & 68 & 68 & 68 \\
\hline oppialat & rho & $-0,14$ & $-0,09$ & 0,05 \\
\hline & $p$ & 0,25 & 0,49 & 0,71 \\
\hline & $N$ & 67 & 67 & 67 \\
\hline
\end{tabular}

Spearmanin järjestyskorrelaatio. 
Osallistujien ikä ja perustaajuuskeskiarvot eivät korreloineet keskenään kummassakaan ryhmässä (Taulukko 2). Perustaajuuskeskiarvojen ja oppialojen välillä ei myöskään ollut korrelaatiota.

\section{POHDINTA}

Saatujen tulosten perusteella näyttää siltä, että suomalaisten naisopiskelijoiden fo on hieman noussut viimeisen kahdenkymmenen vuoden aikana. Opiskelijoiden oppialalla ei näyttänyt olevan tilastollisesti merkitsevää vaikutusta.

Tulosfo:n noususta on päinvastainen verrattuna aiempaan tutkimukseen, jossa vertailtiin 1970- ja 1990-lukuja (Leino ym., 1998). Nyt saatu tulos sen sijaan on samansuuntainen kuin Ketolaisen ym. (2017) saamat tulokset, joiden mukaan 16-17-vuotiaiden tyttöjen fo on noussut verrattuna vuonna 1985 saatuihin tuloksiin (Sallinen-Kuparinen, 1985).

Puhekorkeudella on vahva merkitys ilmaisussa. Korkeahko fo (alle $280 \mathrm{~Hz}$ ) liitetään usein attraktiivisuuteen ja ystävällisyyteen, kun taas matala $f o$ viestii dominanssia ja vakuuttavuutta (Borkowska \& Pawlowski, 2011). Näitä konnotaatioita voidaan selittää myös eläimillä havaitulla frekvenssikoodilla, jonka taustana lienee se, että yleisesti ottaen suurempikokoisilla eläimillä on matalampi ääni (Ohala, 1983): Pelkäävä ja alistuva eläin ääntelee korkeammalla perustaajuudella (siten ikään kuin simuloiden itseään pienempää, vaaratonta olentoa), uhkaava puolestaan matalammalla (siis antaen vaikutelman itseään suurempikokoisesta ja vahvemmasta olennosta). Aiempia tuloksia naisten puheen fo:n laskusta on voitu selittää yrityksenä hakea vakuuttavuutta äänen avulla (Anderson, Klofstad, Mayew \& Venkatachalam, 2014; Pemberton ym., 1998; Valo, 1994). Ketolaisen ym. (2017) tuloksessa nuoret arvioivat oman puhekorkeutensa keskimääräistä matalammaksi. Tähän saattaisi vaikuttaa narinan lisääntynyt käyttö. Esimerkiksi Ketolaisen ym. tutkimuksessa $60 \%$ :lla pojista $(\mathrm{N}=20)$ ja yhtä lukuun ottamatta kaikilla tytöillä $(\mathrm{n}=$ 19) esiintyi narinaa. Tuoreessa tutkimuksessa (Laukkanen \& Rantala, arvioitavana) on todettu, että 73,2 \% suomalaisista naisopiskelijoista käyttää jatkuvaa narinaa lievästi tai kohtalaisesti ja liki 30 \%:lla narinaa esiintyy kohtalaisesti tai erittäin runsaasti (tutkimuksen $\mathrm{N}=104$ ). On mahdollista, että narina saa aikaan virhearvion oman puhekorkeuden mataluudesta, jolloin naiset saattavat tahattomasti nostaa fo: a, jotta korkeus ei omissa korvissa kuulostaisi liian matalalta. Voidaan myös pohtia, onko eri vuosikymmenten näytteissä erimääräisesti esiintynyt narina puolestaan voinut aiheuttaa aiemmissa tutkimuksissa (esim. Leino ym., 1998) sen tuloksen, että fo on laskenut. Asiaa olisi mahdollista selvittää uusilla retrospektiivisillä tutkimuksilla. Toistaiseksi emme kuitenkaan pidä tätä oletusta todennäköisenä, koska Tampereen yliopiston Puheen ja äänen tutkimuksen laboratorion arkistoaineistoja kuuntelemalla vaikuttaa siltä, että narinan esiintyvyys on 1970- ja 1990-luvun luentanäytteissä ollut kaiken kaikkiaan varsin vähäistä.

Lauseintonaation loppunousujen on myöskin todettu lisääntyneen suomen kielen puhujilla (Routarinne, 2003). Olisi mahdollista, että tällaisella tendenssillä olisi osuutta myös saamaamme tulokseen fo-keskiarvojen noususta. Asiaa kannattaa jatkossa selvittää tarkemmin. Näytteitä analysoidessa saamamme kuulovaikutelman perusteella 2010-luvun aineistoamme eivät kuitenkaan leimaa lauseintonaation loppunousut vaan lauseloppujen lisääntynyt narina.

Useiden muiden kielten puhujilla puheen keskimääräinen fo on keskimäärin korkeampi kuin suomen kielen puhujilla. Leinon tutkimusryhmän mukaan suomalaisten naisopiskelijoiden luennan keskimääräinen fo on ollut $194 \mathrm{~Hz}$ (keskihajonta $17 \mathrm{~Hz}$ ) (Leino, 
Laukkanen, Ilomäki, \& Mäki, 2008). Englannin kielen puhujilla on raportoitu naisten keskimääräiseksi $f o$ :ksi luentapuheessa noin $207 \mathrm{~Hz}-217 \mathrm{~Hz}$ Britanniassa (Andreeva, Demenko, Möbius, Zimmerer, Jugler, \& Oleskowicz-Popiel, 2014; Vucovic, Feinberg, DeBruine, Smith \& Jones, 2010; Williams \& Eccles, 1990) ja $210 \mathrm{~Hz}$ Yhdysvalloissa (Pepiot, 2014). Myöskin suomenkielen syntyperäisten puhujien on todettu nostavan puhekorkeuttaan puhuessaan englantia (Järvinen, Laukkanen \& Aaltonen, 2013). Voisiko globaali viihdeteollisuus ja vieraiden kielten, erityisesti englannin, tulo arkeen nykyaikana saada aikaan sen, että myös suomalaisten fo on lähtenyt nousuun? Ketolaisen ym. (2017) tutkimuksen mukaan poikien $f o$ oli kuitenkin laskenut verrattuna vuoden 1985 tutkimukseen, ja saadut lukuarvot $(97 \mathrm{~Hz}$ spontaanipuheessa, $101 \mathrm{~Hz}$ luennassa) ovat varsin matalia verrattuna myös suomalaisten yliopisto-opiskelijoiden keskiarvoihin (Leino ym., 2008). Joko miehillä on menossa puhekorkeuden laskutrendi tai sitten viimeaikaisiin tuloksiin on vaikuttanut narinan suuri yleistyminen, vaikkakin Ketolaisen ym. tutkimuksessa 2017 pyrittiin eliminoimaan narinan vaikutus käyttämällä fo-analyysissa $50 \mathrm{~Hz}$ :n alarajataajuutta. Se ei kuitenkaan liene riittävä poistamaan kaiken tyyppistä narinaa (vrt. Keating, Garellek, \& Kreiman, 2011; Laukkanen \& Rantala, arvioitavana). Asia kaipaa jatkoselvitystä. Myöskin hieman vanhempien kuin teini-iässä olevien miespuhujien puhekorkeuden mahdollista muutosta viime vuosikymmenten aikana olisi syytä tutkia.
Tässä tutkimuksessa on tarkasteltu luennan keskimääräistä $f o$ :a. Vastaako se puheen keskimääräistä fo:a? Sallisen (1985) tutkimuksen mukaan ammattikoululaisilla ja lukioikäisillä nuorilla suomalaisilla luennan fo oli korkeampi kuin puheessa. Samanlaisia tuloksia saivat myös Ketolainen ym. (2017) ja Zraick, Skaggs ja Montague (2000). Järvisen ja Laukkasen (2015) tutkimustuloksien perusteella puolestaan näyttäisi siltä, että suomalaisten puhujien luennan ja spontaanipuheen fo:ssa ei olisi ainakaan keskimääräisesti juuri eroa sen paremmin suomen kielellä kuin vieraallakaan kielellä (englanti) puhuttujen näytteiden välillä. Niin sanotun spontaanipuheen ja luennan perustaajuuden ja muiden piirteiden eroihin tai niiden puuttumiseen voivat vaikuttaa monet seikat kuten se, millaiseksi puhuja kokee äänitystilanteen (ks. esim. Härkönen, 2016).

Puhekorkeuden muutosta olisi syytä tutkia seuraavaksi hieman vanhempien, jo työelämässä toimivien naisten ja miesten keskuudessa. Olisi erittäin mielenkiintoista pyrkiä selvittämään erilaisten puhearkistojen avulla eri-ikäisten ja eri ammattikuntia edustavien henkilöiden spontaanipuheen perustaajuuden mahdollisia eroja eri aikakausien välillä. Myös puhekorkeuteen liitettyjä mielikuvia tulisi selvittää. Vertailu eri-ikäisten kuulijoiden välillä voisi antaa lisävalaistusta siihen, onko kulttuurissamme tapahtunut ja tapahtumassa puhekorkeuteen ja sen viestinnälliseen merkitykseen liittyviä muutoksia. 


\section{LÄHTEET}

Anderson, R.C., Klofstad, C.A., Mayew, W.J. \& Venkatachalam, M. (2014). Vocal fry may undermine the success of young women in the labor market. PloS One, 9, e97506. https://doi. org/10.1371/journal.pone.0097506

Andreeva, B., Demenko, G., Möbius, B., Zimmerer, F., Jugler, J. \& Oleskowicz-Popiel, M. (2014). Differences of pitch profiles in Germanic and Slavic languages. Proceedings of Interspeech, 1307-1311.

Baken, R.J. \& Orlikoff, R. (2000) Clinical measurement of speech and voice. San Diego: Singular.

Bezooijen van, R. (1995). Sociocultural aspects of pitch differences between Japanese and Dutch women. Language and Speech, 38, 253-265.

Boersma, P. \& Weenink, D. (2011). Praat: Doing phonetics by computer [Computer program]. Versio 5.4.05.

Borkowska, B. \& Pawlowski, B. (2011). Female voice frequency in the context of dominance and attractiveness perception. Animal Behaviour, 82, 55-59.

Harris, C.M. \& Weiss, M.R. (1964). Effects of speaking condition on pitch. Journal of the Acoustical Society of America, 36, 933.

Härkönen, R. (2016). Tilanteen vaikutus 14-vuotiaiden pubeen akustisiin ja perkeptuaalisiin piirteisiin. Pro gradu -tutkielma. Tampereen yliopisto: Tampere.

Järvinen, K, Laukkanen, A.-M. \& Aaltonen, O. (2013). Speaking a foreign language and its effect on Fo. Logopedics Phoniatrics Vocology, $38,47-51$.

Järvinen, K. \& Laukkanen, A.-M. (2015). Vocal loading in speaking a foreign language. Folia Phoniatrica et Logopaedica, 67, 1-7.

Keating, P., Garellek, M. \& Kreiman, J. (2011). Acoustic properties of different kinds of creaky voice. Proceedings of the 18 th International Congress of Phonetic Sciences, Glasgow, Scotland, 2011.

Ketolainen, I., Laakso, M. \& Simberg, S. (2017). 16-17-vuotiaiden suomalaisnuorten puheäänen korkeus. Puhe ja kieli, 37, 259-277.

Laukkanen, A.-M. \& Leino, T. (1999). Ibmeellinen ibmisääni: Ä̈̈nenkäytön ja pubetekniikan perusteet, arviointi, mittaaminen ja kehittäminen. Helsinki: Gaudeamus.
Laukkanen, A.-M., Vilkman, E., Alku, P. \& Oksanen, H. (1997). On the perception of emotions in speech: The role of voice quality. Logopedics Phoniatrics Vocology, 22, 157-168.

Laukkanen, A.-M. \& Rantala, L. (arvioitavana). Relations between creaky voice and vocal symptoms.

Leino, T., Laukkanen, A.-M., Kättö, R., Mäki, E. \& Ilomäki, I. (1998). Average fundamental frequency of Finnish female students in the 1970's and in the 1990's. Teoksessa P. Dejonckere \& H.F.M. Peters (toim.), Proceedings of the 24th congress of the International Association of Logopedics and Phoniatrics (IALP), Amsterdam 23-27 August, 1998. Volume I (s. 60-62). IALP: Nijmegen.

Leino, T., Laukkanen, A.-M., Ilomäki, I. \& Mäki, E. (2008). Assessment of vocal capacity of Finnish university students. Folia Phoniatrica et Logopaedica, 60, 199-209.

Lieberman, P. (1967). Intonation, perception and language. Cambridge, Massachusetts.

Nilsonne, Å. (1987). Speech in depression: $A$ methodological study of prosody. Tukholma: Karoliininen instituutti.

Ohala,J.J.(1983). Cross-language use of pitch: An ethological view. Phonetica, 40, 1-18.

Pegoraro-Krook, M. I. (1988). Speaking fundamental frequency characteristics of normal Swedish subjects obtained by glottal frequency analysis. Folia Phoniatrica, 2, 82-90.

Pemberton, C., McCormack, P. \& Russell, A. (1998). Have women's voices lowered across time? A cross-sectional study of Australian women's voices. Journal of Voice, 12, 208-213.

Pepiot, E. (2014). Male and female speech: A study of mean FO, FO range, phonation type and speech rate in Parisian French and American English speakers. Speech Prosody 7, May 2014, Dublin, Ireland, 305-309. halshs-00999332.

Routarinne, S. (2003). Tytöt äänessä. Parenteesit ja nouseva sävelkulku kertojien vuorovaikutuskeinoina. Väitöskirja. Helsinki: Helsingin yliopisto.

Sallinen-Kuparinen, A. (1985). Pitch level and type of oral task. Teoksessa P. Hurme (toim.), Pubeentutkimuksen alalta, 6. Jyväskylän yliopiston viestintätieteiden laitoksen julkaisuja. Jyväskylä: Jyväskylän yliopisto. 
Scherer, K.R. (1979). Personality markers in speech. Teoksessa K. R. Scherer \& H. Giles (toim.), Social markers in speech (s. 147-201). Cambridge: Cambridge University Press.

Scherer, K.R. \& Giles, H. (1979). Social markers in speech. Cambridge: Cambridge University Press.

Valo, M. (1994). Käsitykset ja vaikutelmat ä̈nestä: Kuuntelijoiden arviointia radiopubeen äänellisistä ominaisuuksista. Jyväskylä: Jyväskylän yliopisto.

Vucovic, J., Feinberg, D.R., DeBruine, L., Smith, F.G. \& Jones, B.C. (2010). Women's voice pitch is negatively correlated with health risk factors. Journal of Evolutionary Psychology, 8, 217-225.

Waaramaa-Mäki-Kulmala, T. (2009). Emotions in voice. Acoustic and perceptual analysis of voice quality in the vocal expression of emotions. Väitöskirja. Tampere: Tampereen yliopisto.

Williams, R.G. \& Eccles, R. (1990). A new clinical measure of external laryngeal size which predicts the fundamental frequency of the larynx. Acta Otolaryngologica (Stockholm), 110, 141-148.

Williams, C.E. \& Stevens, K.N. (1972). Emotions and speech: Some acoustical correlates. Journal of the Acoustical Society of America, 52, 1238-50.

Wolk, L., Abdelli-Beruh, N.B. \& Slavin, D. (2012). Habitual use of vocal fry in young adult female speakers. Journal of Voice, 26, 111-116.

Zraick, R.I., Skaggs, S.D. \& Montague, J.C. (2000). The effect of task on determination of habitual pitch. Journal of Voice, 14, 484-489.

Zraick, R.I., Birdwell, K.Y., \& Smith-Olinde, L. (2005). The effect of speaking sample duration on determination of habitual pitch. Journal of Voice, 19, 197-201.

Zraick, R.I., Gentry, M.A., Smith-Olinde, L. \& Gregg, B.A. (2006). The effect of speaking context on elicitation of habitual pitch. Journal of Voice, 20, 545-554. 


\section{CHANGE IN FINNISH FEMALE UNIVERSITY STUDENTS' MEAN FUNDAMENTAL FREQUENCY IN TEXT READING FROM 1990'S TO 2010'S}

Anne-Maria Laukkanen, Speech and Voice Research Laboratory,

Faculty of Social Sciences, Tampere University

Teija Waaramaa, Speech and Voice Research Laboratory,

Faculty of Social Sciences, Tampere University

Habitual speaking pitch is both an individual, situational and social variable. A tendency for a lower speaking pitch in women has been reported in various countries during the last century. Changes in speaking pitch are supposed to reflect changes in the society.

The present study investigates the commonly used correlates of speaking pitch, the mean and median of fundamental frequency, $f o$, in neutral text reading ( 160 words, duration of ca 1 minute) from young 20-25-year-old Finnish female university students in the 1990's and 2010's. The material was derived from the sound archive of Speech and Voice Research Laboratory at Tampere University. We chose randomly samples from 136 females who did not have any known pathologies of the voice or hearing, and whose voice quality sounded normal. The samples were recorded digitally in a well-damped studio using a measuring microphone. The analyses were made using Praat software.

In the results, a small but significant (Student's test $\mathrm{p}<0.001$ ) increase in $f o$ was observed (in the 1990's the fo mean was $195,7 \mathrm{~Hz}$, and in the 2010's it was $210,6 \mathrm{~Hz}$, while the corresponding values of $f o$ median were $190,9 \mathrm{~Hz}$ and $203,2 \mathrm{~Hz}$ ). The change in Finnish female university students' $f o$ may potentially reflect the effect of foreign languages and global entertainment culture.

Keywords: $f o$, effect of culture, speaking pitch 